\title{
Asiasisältöjen raportoinnista esiintymisanalyyseihin
}

\section{Television vaaliohjelmat sanomalehdistön silmin 1960-luvulta 1980-luvulle}

\begin{abstract}
Artikkelissa eritellään ja analysoidaan sitä, miten sanomalehdet ovat kirjoittaneet television vaaliohjelmista 1960-luvulta 1980-luvulle. Analysoitavana ovat Aamulehden, Helsingin Sanomien, Ilta-Sanomien ja Iltalehden kirjoitukset eduskunta- ja presidentinvaaleissa. Aineistosta löytyy selviä eroja eri vuosikymmenten väliltä. 1960- ja 1970-luvuilla vaaliohjelmia käsittelevissä kirjoituksissa vaaliohjelmissa kiinnostaa niiden poliittinen asiasisältö. Poliitikkojen esiintymistyyli ei ole kiinnostuksen aiheena. 1980-luvulle tultaessa sanomalehdet nostavat television uudella tavalla vaalikampanjoinnin keskiöön. Televisiossa tapahtuvalle politiikalle annetaan suuri painoarvo ja vaaliohjelmista rakentuu julkisuudessa merkittäviä mediatapahtumia. Kirjoittelussa korostuu asiakysymysten ohella politiikan visuaalinen puoli, kuten poliitikkojen esiintyminen, pukeutuminen ja elekieli.
\end{abstract}

AVAINSANAT: vaaliohjelmat, Yleisradio, televisio, politiikka, mediahistoria

$\mathrm{T}$ elevision vaaliohjelmien tavoitteena on 1960-luvulta lähtien ollut tarjota julkinen kohtaamispaikka erilaisille yhteiskunnallisille mielipiteille, joita ohjelmissa esiintyvät puolueet edustavat. Samalla kun vaaliohjelmien lähtökohdat ovat pysyneet melko muuttumattomina, on vaaliohjelmien toteutustapa muuttunut vuosikymmenten aikana monin tavoin ja myös suhtautuminen vaaliohjelmiin on vaihdellut. Vaaliohjelmat ja niihin liittynyt kirjoittelu tarjoavat ikkunan siihen, miten politiikan ja median suhteet ovat muuttuneet noina vuosikymmeninä.

Television poliittinen merkitys ja sen yhteiskunnalliset vaikutukset ovat olleet niin akateemisen tutkimuksen kuin journalistisen kiinnostuksen kohteena Suomessa viimeistään 1970-luvulta lähtien (Peltola 1970; Wiio \& Nordenstreng 1972; Pesonen 1972; Suhonen 1975) Ensimmäiset television vaaliohjelmat nähtiin vuoden 1960 kunnallisvaalien yhteydessä, mutta ensimmäisinä todellisina televisiovaaleina on sittemmin ruvettu pitämään vuoden 1966 eduskuntavaaleja, joissa television katsottiin lopullisesti vakiinnuttaneen asemansa keskeisenä vaalikampanjan välineenä (Pesonen 1972, 75). 
Television yleistymisen myötä vaaliohjelmista tuli osa myös sanomalehtien vaalijournalismia. Vaaliohjelmiin liittyvän sanomalehtikirjoittelun volyymi on vaihdellut vaaleittain ja myös suhtautuminen televisioon poliittisen vaikuttamisen paikkana on muuttunut: toisinaan vaaliohjelmien merkitystä on korostettu, toisinaan vähätelty. Myös juttujen fokus on vaihdellut politiikan asiasisältöjä korostavista kirjoituksista poliitikkojen esiintymistä painottaviin kirjoituksiin. Tässä artikkelissa tarkastelen televisiolle ja erityisesti television vaaliohjelmille annettujen merkitysten muuttumista 1960-luvulta 1980-luvulle.

Tutkin, millaisena politiikan foorumina television vaaliohjelmat on eri aikoina nähty, kuinka tärkeinä television vaalikeskusteluita on pidetty ja mihin vaaliohjelmia käsittelevissä kirjoituksissa on kiinnitetty huomiota? Lähtökohtana on ajatus siitä, että television vaaliohjelmiin viittaavat sanomalehtitekstit määrittelevät ja rajaavat televisioon liittyviä luentoja ja tulkintoja (ks. Fiske 1990, 117-124; Ellis 2000, 78-81). Television vaaliohjelmat eivät ole vain tietty ohjelmaformaatti, vaan tiedotusvälineiden, poliitikkojen ja kansalaisten välisessä kanssakäymisessä syntyvien merkityksenantojen summa. Nämä merkityksenannot muuttuvat ajassa ja ovat sidoksissa vallitsevaan poliittiseen ja journalistiseen kulttuuriin.

Lähdeaineistonani ovat presidentin- ja eduskuntavaalien yhteydessä julkaistut sanomalehtikirjoitukset, jotka käsittelevät television vaaliohjelmia. Aineisto on koottu Aamulehdestä, Helsingin Sanomista, Ilta-Sanomista sekä vuodesta 1982 lähtien Iltalehdestä.' Lisäksi olen hyödyntänyt Yleisradion leikearkiston vaaliohjelmia käsittelevää leikekokoelmaa, johon on koottu vaaliohjelmia käsitteleviä artikkeleita suomalaisista sanomalehdistä sekä katsonut Yleisradion tv-arkistossa saatavilla olevat vaaliohjelmat. ${ }^{2}$

\section{Television vaaliohjelmiin liittyvä kirjoittelu tutkimuskohteena}

Artikkeli sijoittuu politiikan ja median suhteita tarkastelevan historiallisen tutkimuksen traditioon. Tyypillisesti median ja politiikan välistä suhdetta on avattu toisaalta haastattelemalla asianomaisia eli poliitikkoja ja politiikan toimittajia (ks. esim. Aula 1991; Pernaa 2007; Pitkänen 2009; Kunelius ym. 2009) tai analysoimalla mediatekstejä. (ks. esim. Isotalus 1998; Salminen 2006; Pernaa \& Pitkänen 2006). Systemaattisia, ajallisen muutoksen huomioon ottavia pitkittäisiä media-aineistoja hyödyntäviä tutkimuksia on tehty vain muutamia (ks. Bastiansen 2006; Langer 2007; Pernaa 2007; Johansson 2008; Väliverronen \& Kunelius 2009; Railo 2011).

Vaaliohjelmia koskeva lehtikirjoittelu tarjoaa myös lisätietoa politiikan ja median välisten suhteiden muutoksista. Television roolia politiikassa on analysoitu historiallisesti Suomessa muutamissa tutkimuksissa, ja myös television vaaliohjelmiin liittynyttä kirjoittelua on käsitelty tai ainakin sivuttu muutamissa opinnäytteissä, tutkimuksissa ja tieteellisissä artikkeleissa (ks. esim. Isotalus 1996; Pernaa 2007; Malin 2010). Systemaattista, ajalliset muutokset huomioon ottavaa tutkimusta aiheesta ei ole kuitenkaan tehty. 
Artikkeli paikantuu myös suomalaisen televisiotutkimuksen tutkimustraditioon, jossa televisiota on lähestytty sen kulttuuristen vaikutusten näkökulmasta. Näissä tutkimuksissa television vaikutuksia ja vastaanottoa on tarkasteltu analysoimalla televisiolle annettuja merkityksiä - ja usein yhden tärkeän lähdeaineiston ovat muodostaneet sanomalehdet (Salmi 1996; Ruoho 2001; Nikunen 2005; Herkman 2005; Elfving 2008; Keinonen 2011). Tutkimusten lähestymistavat ovat vaihdelleet suuresti, mutta yhdistävänä tekijänä on ollut tarkastella televisiota teknologian ja instituution sijaan kulttuurisena muotona (Williams 1975).

Edellä kuvattu tiedotusvälineiden vuorovaikutusta painottava lähestymistapa on mahdollista liittää intermediaalisuuden käsitteeseen, jolla tarkoitetaan yksinkertaisimmillaan eri tiedotusvälineiden välisiä suhteita, jotka ovat kytköksissä omaan aikaansa ja näin ollen myös jatkuvassa muutoksessa. Intermediaalisuuden käsitettä hyödyntävien tutkimusten lähtökohtana on, että median historiallista muutosta on mahdollista ymmärtää paremmin huomioimalla viestinten välisten suhteiden historialliset, yhteiskunnalliset ja kulttuuriset kontekstit. Viestintävälineisiin liittyvät merkitykset rakentuvat näin ollen vuorovaikutuksessa muuhun yhteiskuntaan ja muihin medioihin. (Herkman 2008, 159-160.) Historiantutkimuksen ja intermediaalista lähestymistapaa painottavien tutkimusten yhteys löytyy siitä yhteisestä ajatuksesta, että tiedotusvälineisiin liittyvät historialliset kehityskulut tulevat ymmärrettäviksi vain liitettyinä omiin ajallispaikallisiin konteksteihinsa.

Käsittelen aineistoa ensisijaisesti laadullisen sisällönanalyysin keinoin. Karkeasti jaoteltuna sanomalehtiaineisto jakautuu kahdenlaisiin juttuihin. Ensimmäisen ryhmän muodostavat jutut, joissa käsiteltiin vaaliohjelmien tapahtumia: mitä vaaliohjelmissa sanottiin ja millä tavoin poliitikot esiintyivät? Tämän kategorian jutuista valtaosa on perinteistä uutisjournalismia. Toisen ryhmän muodostivat jutut, joissa käsitellään vaaliohjelmien toteutusta: kuinka hyvin vaaliohjelmasarja toteutettiin ja onnistuivatko toimittajat tehtävässään. Näistä ohjelmien toteutusta arvioivista kirjoituksista valtaosa on pääkirjoituksia ja kolumneja.

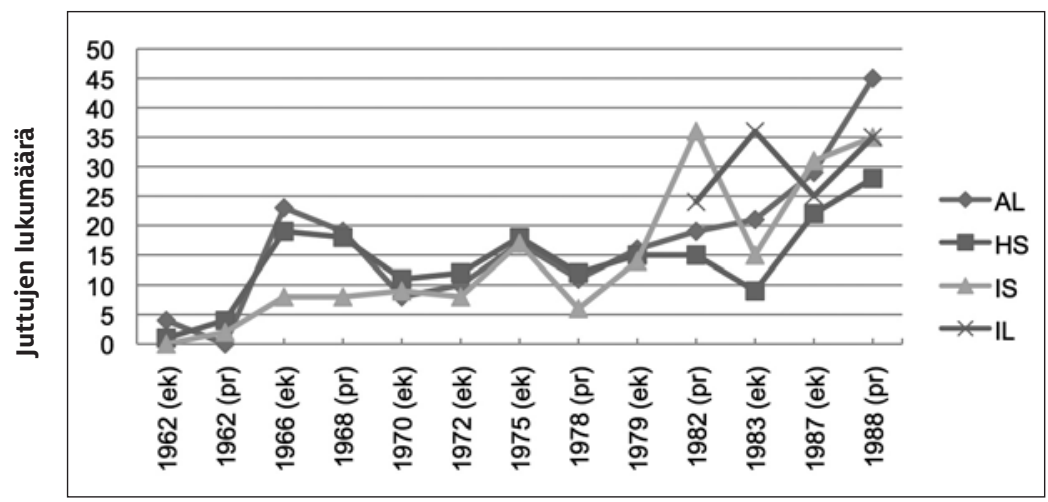

Kuvio 1. Television vaaliohjelmia käsittelevien juttujen lukumäärä Helsingin Sanomissa, Aamulehdessä, Ilta-Sanomissa ja Iltalehdessä 1962-1988 $(\mathrm{N}=538)$ 
Kuviossa 1 esitetään aineiston jakaantuminen määrällisesti sanomalehdittäin. Määrällinen tarkastelu osoittaa, että television vaaliohjelmat ovat olleet osa sanomalehtien vaalijournalismia aina 1960-luvun puolivälistä lähtien. Vaaliohjelmiin alettiin kiinnittää enenevässä määrin huomiota erityisesti 1980-luvulla, vaikkakin juttujen lukumäärissä on suuria eroja sekä vaalien että lehtien välillä. 1960-luvulla vaaliohjelmista kirjoittavat enemmän päivälehdet, kun taas 1980-luvulla painopiste siirtyy iltapäivälehtiin.

Määrälliset muutokset kertovat, millä tavoin vaaliohjelmiin liittynyt kirjoittelu on kehittynyt. Artikkelin kysymyksenasettelun näkökulmasta mielenkiintoisempi kysymys liittyy kirjoittelussa tapahtuneisiin laadullisiin muutoksiin: mihin tekijöihin sanomalehdet ovat vaaliohjelmissa kiinnittäneet eri aikoina huomiota ja minkälaiset tekijät selittävät kirjoittelussa eri vuosikymmenillä tapahtuneita muutoksia? Sanomalehtien kirjoittelua voidaan analysoida uskottavasti vain liittämällä ne osaksi omaa aikaansa. Näin ollen analysoin sanomalehtien kirjoittelua osana suomalaisessa politiikassa ja mediamaisemassa tapahtuneita kehityskulkuja. Artikkelin primaariaineisto koostuu Helsingin Sanomissa, Aamulehdessä, Ilta-Sanomissa ja Iltalehdessä julkaistuista television vaaliohjelmia käsittelevistä kirjoituksista. 1960ja 1970-luvuilla Suomessa oli vielä vahva puoluelehdistö, joten myös puoluelehtien tarkastelu olisi perusteltua. Puoluelehtien systemaattista tarkastelua ei kuitenkaan ole katsottu tarkoituksenmukaiseksi kahdesta syystä. Ensinnä painotan analyysissani televisiolle annettuja merkityksiä. Kävin läpi Yleisradion leikearkistoon kerätyt vaaliohjelmia käsittelevät kirjoitukset ${ }^{3}$, joiden joukossa on muun muassa Kansan Uutisten (SKDL), Suomenmaan (Keskusta), Uuden Suomen (Kokoomus) ja Suomen Sosialidemokraatti -lehden (SDP) juttuja. Otannan perusteella kävi ilmi, että puoluelehdistön tarkastelu veisi analyysin painopistettä vaaliohjelmien pohjalta käytyihin poliittisiin keskusteluihin. Halusin kuitenkin tarkastella yleisemmällä tasolla televisiolle vaalijulkisuudessa annettuja merkityksiä ja näissä merkityksenannoissa tapahtuneita muutoksia.

Toiseksi halusin tutkia kirjoittelun jatkuvuutta, mihin soveltuivat parhaiten sitoutumattomat lehdet. Monien puoluelehtien levikit alkoivat laskea 1950-luvulla ja enemmistö suomalaisista sanomalehdistä oli jo 1960-luvun puolivälissä sitoutumattomia. (Pernaa 2007, 104-105). Puolueita lähellä olevat maakunnalliset ykköslehdet alkoivat viimeistään 1970-luvulta lähtien kehittyä yleislehdiksi, jotka palvelivat laajasti oman alueensa lukijakuntaa. Aatteellisia painotuksia oli lähinnä lehtien mielipideaineistoissa. (Tommila \& Salokangas 1998, 274-278; Salminen 1988, 220-233.) Valittujen sanomalehtien asema ja merkitys sen sijaan säilyvät suomalaisessa sanomalehtijournalismissa vahvana läpi tarkastelujakson. Niiden kirjoittelu muodostaa kiinteän kehityslinjan aina 2000-luvulle, mikä mahdollistaa analogioiden tekemisen myös nykypäivään.

Aineiston sanomalehdet edustavat sekä päivälehtiä että iltapäivälehtiä, valtakunnallisia että maakunnallisia lehtiä. Tampereella ilmestyvä Aamulehti oli kokoomuksen äänenkannattaja aina vuoteen 1992 saakka, mutta lehden valintaa perustelee sen asema oman alueensa johtavana, Suomen laajalevikkisimpänä maakuntalehtenä, 
joka pyrki noudattamaan viimeistään 1970-luvulta lähtien yleisjournalistisia periaatteita. (Salminen 1988, 179-183). Helsingin Sanomat voidaan luokitella valtakunnalliseksi lehdeksi, vaikkakin lukijakunta on painottunut Uudenmaan alueelle. Helsingin Sanomat oli sitoutumaton sanomalehti koko tutkimusjakson ajan, joskin sen porvarillinen edistyspuoluetausta näkyi lehden kirjoittelussa vielä 1960-luvun alussa (Pernaa $2007,21,48$ ). Iltapäivälehtien valinta on perusteltua paitsi niiden laajojen levikkien vuoksi myös siksi, että ne ovat tuoneet uusia journalistisia käytäntöjä Suomeen (Kivioja 2008, 204-205). Ilta-Sanomat perustettiin vuonna 1932 sitoutumattomaksi ja se kuuluu samaan lehtiyhtymään kuin Helsingin Sanomat. Iltalehti alkoi ilmestyä lokakuussa 1980 Uuden Suomen iltapäiväpainoksena.

\section{0-Iuvun televisio politiikan foorumi muiden joukossa}

Televisio tuli Suomeen 1950-luvun lopulla ja vakiinnutti nopeasti asemansa maan seuratuimpana tiedotusvälineenä (Ilmonen 1996, 192). Politiikka löysi tiensä kansalaisten olohuoneisiin, kun television uutistoiminta käynnistyi 1950-luvun lopulla. Ensimmäiset television vaaliohjelmat esitettiin vuoden 1960 kunnallisvaalien yhteydessä, ja 1960-luvun aikana erilaiset yhteiskunnalliset ohjelmasisällöt vakiintuivat osaksi television ohjelmistoa.

Samalla kun televisio vakiinnutti asemiaan suomalaisessa mediamaisemassa 196o-luvulla, oli suomalainen lehdistökenttä voimakkaiden muutosten keskellä. Puoluelehdistön asema alkoi heikentyä nopeasti toisen maailmansodan jälkeen ja yhä useampia sanomalehtiä lakkautettiin. Menestyneimmät maakuntien ykköslehden aseman saavuttaneet sanomalehdet ottivat uutisjournalismissaan tavoitteekseen objektiivisuuden. (Tommila \& Salokangas 1998, 274-278; Salminen 1988, 220233.)

Jatkuvasti vahvistuville sitoutumattomille ja markkinaehtoisesti toimiville sanomalehdille televisio näyttäytyi sekä uhkana että mahdollisuutena. Kun lehdistön levikit alkoivat 1960-luvulla pienentyä, syypäänä pidettiin herkästi televisiota. Sanomalehtien liiton vuosikokouksessa harkittiin 1960-luvun alkuvuosina jopa ohjelmatietojen julkaisemisen lopettamista, mikäli Yleisradio ei suostu maksamaan niistä sanomalehdille. (Kilpi 2007, 142). Lehdistössä vastustettiin myös tv-mainontaa, koska sen pelättiin heikentävän lehtien ilmoitustuloja (Salokangas 1996, 143). Toisaalta televisio-ohjelmat tarjosivat jo 1960-luvulla sanomalehdistölle runsaasti juttuaiheita ja keskustelua käytiin niin televisiopolitiikasta, televisiotoiminnassa noudatettavista toimintaperiaatteista kuin televisio-ohjelmista ja niissä esiintyvistä henkilöistä. (Keinonen 2011, 64-74, 93-96; Elfving 2008).

Myös poliitikoille televisio näyttäytyi tärkeänä ja kiinnostavana uutena tiedotusvälineenä, jonka vaikutusvaltaa poliitikot pitivät merkittävänä jo 1960-luvulla (Hemánus 1972, 248; Pernaa 2007, 32). Vaaliohjelmia pidettiin tärkeinä erityisesti siksi, että niitä katsoivat niin monet. Television vaaliohjelmat keräsivät ja keräävät edelleen niin Suomessa kuin maailmanlaajuisestikin suurempia yleisöjä kuin 
yksikään muu kampanjatapahtuma. Lisäksi vaaliohjelmista on uutisoitu lähes poikkeuksetta muissa tiedotusvälineissä. (McKinney \& Carlin 2004, 203-204; Pernaa 2007, 52.)

Suomessa politiikkaa käsitteleviä ohjelmia tuotti 1960-luvulta 1980-luvulle ainoastaan Yleisradio. Yleisradio oli puolestaan tiukasti poliittisesti valittujen hallintoneuvoston ja ohjelmaneuvostojen käsissä, joten myös television vaaliohjelmien järjestämiseen liittyvät kysymykset olivat avoimen poliittisia. Poliittisen ohjelmiston päällimmäisenä lähtökohtana oli 1950-luvulta lähtien tasapuolisuuden vaatimus, jota puolueiden edustajat tarkkaavaisina vahtivat ohjelmaneuvostoissa. Yleisradion ohjelmajohdon tavoitteena oli puolestaan estää kiistely yhtiön lähetyksissä. (Salokangas 1996, 45-46.)

Television vaaliohjelmat jakautuivat 1960-luvulta lähtien vaalitentteihin ja suureen vaalikeskusteluun. Vaalitentit järjestettiin 1960-luvulla siten, että kuhunkin tenttiin kutsuttiin edustus kaikista puolueista ja kysymyksiä esittivät toisilleen toimittajien sijaan poliitikot. Vuorossa olleen puolueen edustaja esitteli puolueen vaaliohjelmaa, jonka jälkeen kilpailevien puolueiden edustajat esittivät kysymyksiä niin sanotulle "altavastaajalle" eli tenttivuorossa olevan puolueen edustajalle. Poliitikot alustivat usein kysymyksensä voimakkailla aatteellisilla kannanotoilla, jotka kertoivat puolueiden ideologisista eroista. Suurissa vaalikeskusteluissa puolueiden ehdokkaat pitivät vuorotellen puheenvuoroja ja kilpailevien puolueiden edustajilla oli mahdollisuus esittää lyhyitä repliikkejä. Suuret vaalikeskustelut olivat radion ja television yhteislähetyksiä ja niihin valittiin puheenjohtaja tyypillisesti Yleisradion johdosta. Puheenjohtajan tehtäväksi jäi puheenvuorojen jakaminen. Toimittajia ei nähty sen paremmin vaalitenteissä kuin suuressa vaalikeskustelussakaan. (Valitsijamiesvaalikeskustelu, Yle TV1 9.1.1962; Valitsijamiesvaalikeskustelu, Yle TV1 4.1.1968.)

Millä tavoin television vaaliohjelmat sitten näkyivät sanomalehdistön kirjoittelussa? Kuten kuviosta 1. voi havaita, vaaliohjelmista kirjoiteltiin jonkin verran jo 1960-luvulla. Huomion arvoista kuitenkin on, että kirjoittelun painopiste oli hyvin erilainen kuin myöhempinä aikoina. Television vaaliohjelmien kohdalla sanomalehdistön päähuomio kiinnittyi ensisijaisesti vaaliohjelmien järjestämiseen liittyviin poliittisiin kysymyksiin, kun taas vaaliohjelmien tapahtumista kertovia uutisia laadittiin verrattain vähän. Uutisten määrällisen vähäisyyden voidaan arvioida kertovan siitä, etteivät sanomalehdet pitäneet television vaaliohjelmia vielä 1960-luvulla erityisen tärkeinä poliittisina tapahtumina.

Merkille pantavana seikkana voidaan pitää sitä, että erityisesti 1960-luvulla päivälehdet kirjoittivat television vaaliohjelmista huomattavasti enemmän kuin iltapäivälehdistöä edustanut Ilta-Sanomat (ks. kuvio 1). Taisto Hujasen ja Lennart Weibullin $(2010,104)$ tutkimuksen mukaan Helsingin Sanomat kirjoitti ylipäätään 1960-luvun alkuvuosina televisiosta aktiivisemmin kuin Ilta-Sanomat. Tilanne lienee kuitenkin muuttunut nopeasti vuosikymmenen edetessä, sillä jo 1960-luvun puolivälissä Ilta-Sanomien päätoimittaja linjasi television olevan tärkeä foorumi uutisarvoisille tapahtumille (Kilpi 2007, 142). 
Vaikka Ilta-sanomat toisaalta käsitteli sivuillaan politiikkaa 1960-luvulla varsin usein ja lehti otti television jo varhaisessa vaiheessa omakseen, eivät television vaaliohjelmat ylittäneet lehden uutiskynnystä kuin harvoin. Näissä harvoissa kirjoituksissa Ilta-Sanomilla oli kuitenkin jo 1960-luvulla omintakeinen tyylinsä. Laatiessaan yhteenvedon vuoden 1966 suuresta vaalikeskustelusta Ilta-Sanomien jutussa listattiin esimerkiksi keskustelun "epäselvimmät kannanotot, selvimmät kannanotot, asiattomimmat tempaukset ja ontuvimmat perustelut" (IS 19.3.1966). Käsittelytavassa oli yllättävän paljon samoja elementtejä kuin päivälehtien 1990- ja 2000-luvulla julkaisemissa vaalitenttejä käsittelevissä uutisissa.

Päivälehdissä vaaliohjelmat ylittivät uutiskynnyksen hieman useammin jo 1960-luvulla, mutta verrattuna 1980-Iukuun juttuja oli varsin vähän. Aamulehden uutisissa saatettiin esitellä korostetusti kokoomuksen ehdokkaiden puheenvuoroja, mutta tyypillisesti vaaliohjelmia käsittelevissä uutisjutuissa huomio kiinnittyi keskustelujen asiasisältöihin ja niissä vältettiin ottamasta kantaa esimerkiksi ehdokkaiden pärjäämiseen tai esiintymiseen (AL 20.3.1966; AL 15.5.1967; AL 5.1.1968). Äärimmäisenä esimerkkinä asiakeskeisestä uutisjournalismista voidaan pitää Helsingin Sanomien vuoden 1968 presidentinvaalitenttejä käsitteleviä juttuja, joissa vaalikeskustelut oli litteroitu lehteen lähes sanasta sanaan. "Seuraavassa keskustelun pääsisältö (väliotsikot toimituksen laatimia)", kerrottiin Helsingin Sanomien vaaliohjelmia käsittelevien uutisjuttujen alussa. (HS 3.1.1968; HS 4.1.1968; HS 5.1.1968.) ${ }^{4}$

Uutisjournalismin tapa kirjoittaa television vaaliohjelmista ilmensi 1960- ja 1970-lukulaista politiikkakäsitystä, jonka ytimessä olivat yhteiskunnalliset mielipiteet ja politiikan asiakysymykset. Vaaliohjelmat toteuttivat niille annettua perustehtävää eli ne tarjosivat äänestäjille tietoa poliitikkojen ja puolueiden tavoitteista. Sanomalehdet toistivat lähes sanatarkasti ohjelmissa esitetyt mielipiteet. Näin ollen vaaliohjelmia käsittelevät kirjoitukset eivät olennaisella tavalla eronneet muusta vaaliuutisoinnista, joka raportoi tyypillisesti ehdokkaiden maakunnissa pitämien poliittisten puheiden sisällöistä. Uutisjournalismin näkökulmasta oli yhdentekevää pitikö poliitikko puheensa televisiossa vai puolueen tupaillassa - poliitikon puheen uutisarvon ratkaisi sen sisältö. Tästä käytännöstä poikettiin 1960- ja 70-lukujen uutisjournalismissa vain muutamia kertoja.

Mielenkiintoinen yksityiskohta vaaliohjelmia käsittelevissä kirjoituksissa liittyy niiden tapaan sivuuttaa television visuaalinen ulottuvuus poliitikkoja arvioitaessa. Poliitikot olivat alkaneet kiinnittää huomiota television vaaliohjelmien visuaaliseen luonteeseen jo 1960-luvulla. Yhtenä 1960-luvun taitavana poliittisena ja television visuaalisuuden huomioon ottavana siirtona pidettiin SDP:n puoluesihteeri Kaarlo Pitsingin oivallusta kirjoittaa puolueen kahdeksan kohdan ohjelma kartongille ja esitellä se television välityksellä yleisölle (Sisättö 1977, 98). Kielteisempää palautetta sai TPSL:n eli Työväen ja pienviljelijäin sosiaalidemokraattisen liiton Olli Uoti, joka samaisessa vaalikeskustelussa pystytti näkyville puolueensa puheenjohtajan Aarre Simosen vaalimainoksen ehdokasnumeroineen (IS 19.3.1966). Erilaista rekvisiittaa poliitikot toivat vaalikeskusteluihin myös 1970-luvun ja 1980-luvun vaalikeskusteluissa, kun Pitsingin ideoiman kartonkimetodin oli omaksunut moni muukin 
puolue ja poliitikko (Suuri vaalikeskustelu, Yle TV1 30.12.1971; Suuri vaalikeskustelu 1.1.1987). Sanomalehdistössä vaaliohjelmien visuaalista puolta ei sen sijaan 1960- ja 1970-luvuilla tuotu esiin. Uutisista ei voinut niissä käytetyn kielen perusteella päätellä kyseessä olleen nimenomaan televisiokeskustelu esimerkiksi radiokeskustelun sijaan, ellei asiaa jutussa erikseen mainittu.

\section{Puoluejohtoista vaalivalistusta}

Siinä missä 1960- ja 1970-lukujen Suomessa television vaaliohjelmat ylittivät journalistiset uutiskriteerit melko harvoin, arvioitiin vaaliohjelmien toteutusta hieman useammin pääkirjoituksissa ja kolumneissa. Kirjoitukset kertoivat omasta aikakaudestaan kiinnittymällä toisaalta vaaliohjelmien erilaiseen toteutustapaan, toisaalta aikakauden erilaiseen tapaan hahmottaa politiikkaa. Koska ohjelmia ei toteutettu journalistisista lähtökohdista, niitä ei myöskään lehdistössä arvioitu televisio-ohjelmina, vaan puolueiden järjestäminä tilaisuuksina tai kansalaisille suunnattuna vaalivalistuksena, kuten Aamulehdessä asia ilmaistiin (AL 20.3.1966). Televisiotenttien onnistuminen tai epäonnistuminen, kiinnostavuus tai kiinnostamattomuus, oli siis sanomalehtien näkökulmasta ensisijaisesti kiinni poliitikoista.

Suhtautuminen vaaliohjelmiin vaihteli vaalista vaaliin. Tyypillisesti poliitikkoja kritisoitiin epäselvistä vastauksista ja kiertelystä. Aatteellisten puheenvuorojen katsottiin peittävän alleen todelliset poliittiset asiakysymykset ja niiden ratkaisuvaihtoehdot (HS 11.1.1962; HS 20.1.1962). Vuoden 1962 eduskuntavaalien alla esimerkiksi Helsingin Sanomissa moitittiin "liirum-laarum" -vaaliohjelmia murheellisiksi ja ihmeteltiin, eikö näiden poliittisten ohjelmien tason korottamiseksi ole mitään tehtävissä:

\section{Eduskuntavaalien johdosta touhotetaan Yleisradiossa ja Suomen Televisiossa ikävää} ja mielenkiinnotonta "kysy sinä - minä vastaan" -leikkiä. Ennen tämän leikin alkua saadaan kuulla minuuttikaupalla puoluefraseologiaa. (HS 20.1.1962)

Poikkeuksen 1960- ja 70-lukujen kriittiseen yleislinjaan tarjoavat vuoden 1966 vaalit, joiden yhteydessä vaaliohjelmia arvioitiin myös myönteisessä valossa. Useissa kirjoituksissa ohjelmia pidettiin kansalaisten näkökulmasta informatiivisina ja televisiossa nähdyn poliittisen keskustelun yleisen tason arvioitiin parantuneen merkittävällä tavalla aikaisemmista ajoista. Tämä näkemys tuli esille laajasti kaikissa aineiston sanomalehdissä (HS 12.3.1966; HS 19.3.1966; IS 11.3.1966; AL 12.1.1966; AL 25.2.1966). Esimerkiksi Aamulehden Kuvaruudusta -palstan kolumnistin mukaan vaalikeskustelut olivat aiemmin olleet suoranaisia riitelytilaisuuksia, mutta tällä kertaa keskustelut olivat ilahduttavasti edenneet asiallisissa ja maltillisissa merkeissä, eikä kukaan "ollut erehtynyt esittämään epärehtiä propagandaa" (AL 12.10.1966).

Olivatpa arviot kielteisiä tai myönteisiä, niitä yhdisti hyvin samankaltainen käsitys onnistuneesta vaaliohjelmasta. 1960-luvulla hyvän, onnistuneen tai tavoiteltavan vaaliohjelman mittapuuna ei toiminut poliitikkojen välinen taitava ja värikäs sanankäyttö, 
jännittävät konfliktit tai poliitikkojen karismaattinen esiintyminen. Hyvän esiintymisen reunaehdot määrittyivät suhteessa siihen, kuinka arvokkaasti, sivistyneesti ja asiapohjaisesti poliitikot ohjelmissa argumentoivat.

Vaaliohjelmien toteutusta arvioivien kirjoitusten ohella otsikoihin nousivat toisinaan myös vaaliohjelmien toteuttamiseen liittyneet poliittiset kiistat. Yleisradion ohjelmaneuvostoissa kiisteltiin puolueiden esiintymisjärjestyksestä, ohjelmien puheenjohtajista ja siitä, kuinka monta edustajaa kustakin puolueesta televisioon valitaan. Poliitikoille ja puolueille vaaliohjelmien toteutukseen liittyvät yksityiskohdat olivat tärkeitä ja tasapuolisuuden toteutumiseen liittyvät kiistat saivat palstatilaa myös sanomalehdistössä. Keskustelu heijasteli 1960-lukulaista asetelmaa, jossa puolueiden valvomaan Yleisradioon liittyi runsaasti poliittisia kiistoja.

Esimerkiksi vuoden 1966 eduskuntavaaleissa sanomalehdistössä kirjoiteltiin vaaliohjelmien aikatauluun liittyneestä kiistasta, jossa ohjelmaneuvoston silloisen puheenjohtajan Johannes Virolaisen (kesk.) katsottiin vetäneen ohjelmajärjestelyissä kotiin päin. Vaaliohjelmat suunniteltiin käynnistettäväksi kaksi kuukautta ennen vaaleja ja totuttuun tapaa puolueiden esiintymisjärjestys arvottiin. Ensimmäiseksi tentittäväksi arpa määräsi keskustan. Arvonnan jälkeen vaaliohjelmien aikataulua haluttiin keskustan esityksestä muuttaa tiiviimmäksi siten, että kaikki vaalitentit toteutettaisiin lähempänä vaaleja. Muissa puolueissa aikataulumuutos tulkittiin keskustan poliittiseksi taktikoinniksi, joka oli seurausta puolueen huonosta arpaonnesta. Ohjelmaneuvostossa päätös aikataulumuutoksesta kuitenkin hyväksyttiin neuvoston puheenjohtajan Johannes Virolaisen ratkaisevalla äänellä. (HS 20.1.1966; AL 19.1.1966; AL 18.1.1966.)

Vastaavanlaisia riitoja nähtiin myös 1970-luvulla liittyen esimerkiksi vaaliohjelmissa jaettujen puheenvuorojen ajalliseen kestoon. Vuoden 1972 eduskuntavaaleissa SDP:n puoluesihteeri Kalevi Sorsa moitti suurta vaalikeskustelua epätasapuoliseksi. Aihe ylitti sanomalehdistön uutiskynnyksen ja esimerkiksi Ilta-Sanomat uutisoi Yleisradion selvityksen perusteella puolueiden käyttämien puheenvuorojen kestot sekunnin tarkkuudella (IS 5.1.1972). Puheenvuorojen kestosta uutisoidaan edelleen 2000-luvullakin (esim. 45-minuuttia, MTV3 11.1.2012), mutta toisin kuin 2000-luvulla, 1970-luvulla tasapuolisuuden vaatimukseen suhtauduttiin poliitikkojen keskuudessa ja sitä kautta myös Yleisradiossa äärimmäisellä vakavuudella. Kalevi Sorsan kritiikki johti Yleisradiossa viralliseen selvitykseen, jonka tulokset julkistettiin myöhemmin syksyllä. "Suuri vaalikeskustelu ei ollut tasapuolinen", uutisoi Helsingin Sanomat (HS 17.9.1972).

Vuoden 1975 vaaleissa riideltiin puolestaan ohjelmakoordinaatioon liittyvistä kysymyksistä, kun SDP vaati TV2:n ohjelmakarttaan muutoksia oman vaalitenttinsä ajaksi. SDP:n tentin aikana päällekkäin esitettiin TV2:Ila etsivä Columboa. SDP:ssä tämän arvioitiin vievän kohtuuttomasti potentiaalisia katsojia SDP:n vaaliohjelmalta. SDP voitti kiistan ja Columbo siirrettiin esitettäväksi uutena ajankohtana. Sanomalehdistö uutisoi tämän kiistan yksityiskohtaisesti, vaikkakin pääkirjoituksissa ja kolumneissa SDP:n toimintaa pidettiin ylimitoitettuna. (IS 12.9.1975; HS 12.9.1975; AL 21.9.1975)

Edellä kuvatut vaaliohjelmien toteutusta koskevat kiistat liittyivät elimellisesti Yleisradion asemaan poliittisesti valvottuna organisaationa, jossa puolueet vahtivat 
pikkutarkasti tasapuolisuuden toteutumista ohjelmistossa. Samalla kiistat kuitenkin osoittivat, että puolueiden ja poliitikkojen keskuudessa television ja vaaliohjelmien merkitystä pidettiin niin suurena, että puolueilla oli halua puuttua jopa lähetysaikatauluihin. Vaikuttaakin siltä, että poliitikkojen ja sanomalehtitoimittajien suhtautumisessa vaaliohjelmiin ja television poliittiseen merkitykseen vallitsi 1960- ja 1970-luvuilla mielenkiintoinen epäsuhta. Kiistellessään vaaliohjelmien toteutukseen liittyvistä yksityiskohdista poliitikot osoittivat arvostavansa television poliittisen painoarvon korkealle. Samanaikaisesti sanomalehdistö ylläpiti journalismissaan omaa asiakeskeisempää lähestymistapaansa, jonka näkökulmasta television vaaliohjelmien antama lisäarvo poliittiselle keskustelulle oli vähäinen.

\section{Kohti journalistisempia vaaliohjelmia}

Television ja Yleisradion näkökulmasta 1960-luvun loppuun liittyy runsaasti tärkeitä kehityskulkuja. Yleisradion ohjelmapolitiikka oli ollut kasvavan kritiikin kohteena aina vuoden 1966 vaaleista lähtien, jolloin Yleisradiota syytettiin vasemmiston avoimesta tukemisesta vaaleissa (Pernaa 2007, 42-43). Yleisradion historiassa sivuuttamaton Reporadio ja sen ohjelmapolitiikkaan liittynyt kritiikki leimasi 1960-luvun lopun Yleisradioon liittyviä keskusteluja ja nousi yhdeksi tärkeäksi vaaliteemaksi vuoden 1970 eduskuntavaaleissa. Kehityskulku liittyi 1960-luvun yhteiskunnalliseen ja poliittiseen turbulenssiin, jonka tekivät Yleisradiossa näkyviksi nuoremman sukupolven toimittajat uudenlaisine kantaaottavine ohjelmasisältöineen. (Salokangas 1996, 151-155, 217246.)

Tässä yhteydessä ei ole syytä käydä yksityiskohtaisesti läpi Reporadioon liittyviä vaiheita ${ }^{5}$, mutta todettakoon, että 1960-Iuvun lopun ja 1970-luvun alun Yleisradioon liittyneellä kuohunnalla oli välillinen vaikutuksensa myös vaaliohjelmiin ja niiden toteutukseen. Poliittisen ohjelmiston näkökulmasta uudenlaista journalistista tyyliä edusti esimerkiksi Eino S. Revon 1966 perustama erikoistoimitus, jonka keulahahmona toimi Reino Paasilinna. Paasilinnan yhteiskunnallisesti kantaa ottavat ja "radikaalit" ohjelmat herättivät runsaasti kriittistä keskustelua aikalaisten keskuudessa. (Emts. 222.) Poliittis-ideologisten painotusten ohella televisio-ohjelmissa esiintyneen väkivallan ja seksin pelättiin rapauttavan kansan moraalista selkärankaa. (Heiskanen 1986, 93-94.)

Mielipahaa aiheutti osalle katsojista myös Yleisradion uudenlaiset ohjelmaformaatit, joissa politiikkaa käsiteltiin aiempaa kriittisemmin. Hyvänä esimerkkinä tällaisesta ohjelmasta toimii poliitikkojen haastatteluohjelma Peukaloruuvi (1967-1969), jossa hyödynnettiin ensimmäisiä kertoja Suomen televisiohistoriassa niin sanottua revolverihaastattelutekniikkaa, jossa toimittaja keskeytti ja kyseenalaisti poliitikon sanomisia. (Pernaa 2007, 54-55; Koski 2010, 101.) Ohjelmassa juontajana toimineen Seppo Tikan mukaan palaute ohjelmasta oli lähes poikkeuksetta kielteistä. Toimittajia moitittiin puolueellisiksi ja myös hyökkäävää tyyliä paheksuttiin (Kuvaruudun ehdoilla, Yle TV2 15.2.1995). 
Siinä missä 1960-luvun puolivälin jälkeen tapahtuneen kehityksen voidaan katsoa radikaalilla tavalla muuttaneen Yleisradion ohjelmapolitiikkaa ja vastaavasti 1970-luku näyttäytyy tässä kehityksessä normalisoinnin aikakautena, muuttivat vaaliohjelmat muotoaan yleistä kehitystä huomattavasti hitaammassa aikataulussa. Vaaliohjelmissa tasapuolisuuden periaate säilyi loukkaamattomana myös Reporadion aikakaudella, eikä 1960-luvun jälkipuoliskon kuohunnasta näkynyt merkkiäkään vaaliohjelmissa. Kehityskulku kohti journalistisempia vaaliohjelmia käynnistyi oikeastaan vasta vuoden 1970 eduskuntavaalien alla, ja voimakkaimmat muutokset ajoittuvat pikemminkin 1970-luvun puoliväliin. (Salokangas 1996, 265-266, 270-275.)

Vuoden 1970 eduskuntavaaleissa toimittajat pääsivät ensimmäistä kertaa mukaan vaalitentteihin, kun vaalitenttisarjan puheenjohtajiksi valittiin Peukaloruuvista tutuksi tulleet toimittajat Seppo Tikka ja Pentti Lumme. Vaalitenteissä toimittajien rooli säilyi kuitenkin edelleen vähäisenä, mutta aiemmista vaalitenteistä poiketen toimittajat saivat tehdä täydentäviä kysymyksiä puolueiden edustajille. Ohjelmien painopiste oli kuitenkin edelleen puolueiden edustajien toisilleen esittämillä kysymyksillä. Suuressa vaalikeskustelussa puheenjohtajan roolina oli edelleen puheenvuorojen keston mittaaminen ja tasapuolisuuden varmistaminen.

1970-luvun alkupuoliskolla tasapuolisuusvaatimusta kohtaan alettiin kuitenkin esittää yhä enemmän kritiikkiä myös puolueiden keskuudesta. Kritiikki ei kuitenkaan kohdistunut tasapuolisuuteen vaaliohjelmissa sinänsä, vaan siihen, keiden tulisi saada osallistua vaaliohjelmiin ja millä tavoin ohjelmistossa huomioitaisiin parlamentaariset voimasuhteet. Erityisesti SDP:n mielestä hedelmällistä keskustelua ei voinut syntyä, kun keskustelijoita oli lukumääräisesti niin paljon. Pienet puolueet taas pitivät kiinni oikeudestaan saada yhtä paljon lähetysaikaa kuin suuretkin puolueet. (Salokangas 1996, 265-266.) Vaaliohjelmien kohdalla pyrkimyksenä oli jättää television vaalikeskusteluiden ulkopuolelle ne puolueet, joilla ei ollut kansanedustajia eduskunnassa. Kiista ratkesi vuoden 1975 eduskuntavaalien alla, kun oikeuskansleri torjui Yleisradion hallintoneuvoston kannan ja edellytti kaikkien puolueiden saavan vaaliohjelmissa tasapuolista kohtelua.

Vaikkei toive vaaliohjelmien osallistujajoukon karsimisesta toteutunutkaan, vuoden 1975 vaalien yhteydessä vaaliohjelmistoa kuitenkin uudistettiin monin tavoin. Vaalitenttien osalta käytäntö, jossa yksi puolue vuorollaan vastasi muiden kysymyksiin lopetettiin, ja poliitikkoja alkoivat tentata puolueiden edustajien sijaan toimittajat. Käyttöön otettiin ensimmäistä kertaa myös muista poliittisista haastatteluohjelmista tutuksi tullut aggressiivisempi tyylilaji. Toimittajat haastoivat aktiivisesti poliitikkoja ja toisin kuin puoluevetoisissa vaalitenteissä, toimittajat esittivät poliitikoille välihuomautuksia ja joskus jopa keskeyttivät heidän puheenvuoronsa (ks. esim. AL 13.9.1975). Vuodesta 1975 lähtien vaaliohjelmia tehtiin toimittajavetoisesti ja vaalitenttien osalta poliitikkoja pyrittiin haastamaan aiempaa aktiivisemmin myös tulevissa vaalitenteissä.

Uudenlaisten vaaliohjelmien kruununa oli aivan uudentyyppinen suuri vaalikeskustelu yleisöineen, yleisökysymyksineen ja yleisöäänestyksineen. Tilaisuuden puheenjohtaja toimittaja Arto Tuominen hauskuutti yleisöä välihuomioillaan, ja uudenlaista 
keveyttä ohjelmaan toivat myös yleisön taputukset ja naurunpurskahdukset. Uudenlaisen asetelman innoittamina myös osa poliitikoista pyrki aktiivisesti hauskuttamaan yleisöä nokkelilla sutkautuksilla. (Suuri vaalikeskustelu, Yle TV1 18.9.1975.) Vuoden 1975 suuri vaalikeskustelu oli viihteellisyydessään poikkeuksellinen. Yleisöjä suurissa vaalikeskusteluissa nähtiin seuraavan kerran vasta 1990-luvulla MTV3:n aloitettua omien vaaliohjelmiensa teon. Suurien vaalikeskusteluiden osalta Yleisradiossa palattiin 1970luvun lopulla hidastempoisempiin keskusteluihin, joissa poliitikoille annettiin enemmän tilaa esittää rauhassa omia näkökantojaan sen paremmin toimittajien kuin vastaehdokkaiden häiritsemättä.

Toimittajien mukaantulo näkyi odotetusti myös sanomalehdistön kirjoittelussa, jota oli vuoden 1975 vaaleissa huomattavasti enemmän kuin edeltävissä vaaleissa (ks. kuvio 1). Uudenlaiset vaaliohjelmat kirvoittivat vilkkaan julkisen keskustelun niiden toteutustavasta ja keskusteluun osallistuivat niin kansalaiset, poliitikot kuin toimittajatkin. Kielteistä palautetta ohjelmantekijät saivat ensinnäkin haastattelumetodista, jota pidettiin liian päällekäyvänä. Toisaalta julkisuudessa käytiin keskustelua ohjelmien tasapuolisuudesta (AL 20.8.1975; AL 22.8.1975; HS 13.9.1975; HS 18.9.1975; IS 21.8.1975; IS 23.8.1975; IS 3.9.1975). Esimerkiksi Ilta-Sanomien TV ja radio -palstalla vaaliohjelmia arvioi toimittaja Aila Niinimaa, jonka mukaan toimittajat "laukovat kysymyksiä, keskeyttävät vastauksia, hyökkäävät asiayhteyksistään erotetuilla lainauksilla, käyttävät purevaa ivaa missä siihen on suinkin mahdollisuus". Niinimaan mukaan vaaliohjelmiin liittyvien uudistusten tarkoituksena oli ollut päästä eroon miltei "tukkanuottasia hipovista puolueitten välisistä väittelyistä ja tässä oli onnistuttu: nyt olivat tukkanuottasilla toimittajat ja poliitikot". (IS 3.9.1975)

Käsitykset onnistuneesta vaaliohjelmasta säilyivät siis ennallaan ohjelmaformaateissa tapahtuneista muutoksista huolimatta. Siinä missä 1960-luvulla kritiikin kohteeksi nousivat keskenään riitelevät poliitikot, jotka omalla käyttäytymisellään heikensivät politiikan arvovaltaa, nousivat vuoden 1975 vaaleissa kritiikin keskiöön politiikan toimittajat, joiden tulisi "irtohuulien ja naljailun" sijaan haastaa poliitikot asioilla (HS 18.9.1975).

Uutisjournalismiin 1970-luvun jälkipuolisko toi pieniä muutoksia. Päivälehdille vaaliohjelmat olivat edelleen melko vähämerkityksisiä poliittisia tapahtumia, joista laadittiin vain muutamia keskustelujen asiasisältöjä käsitteleviä pieniä uutisia, mutta IltaSanomille television vaaliohjelmat alkoivat pikku hiljaa näyttäytyä yhä mielenkiintoisempana jutun aiheena. Vuoden 1975 eduskuntavaalien alla lehdessä julkaistiin lukuisia reportaaseja, joissa kuvailtiin yksittäisten vaaliohjelmien tapahtumia, vaikkakin juttujen päähuomio kiinnittyi edelleen poliitikkojen puheisiin. (IS 19.8.1975; IS 9.9.1975; 10.9.1975; 11.9.1975; IS 12.9.1975; 19.9.1975)

Arvioitaessa 1970-lukua kokonaisuutena voidaan kuitenkin havaita, ettei sanomalehdistön tavoissa käsitellä television vaaliohjelmia tapahtunut olennaisia muutoksia verrattuna 1960-lukuun. Uutisjournalismin puolella vaaliohjelmien uutisarvo oli melko vähäinen, ja toimittajien kiinnostus kohdistui ensisijaisesti poliitikkojen poliittisiin linjauksiin. Esimerkiksi poliitikkojen elekieleen tai esiintymiseen liittyvät arviot olivat poikkeuksellisia. Toimittajien mukaantulo ohjelmien tekoon lisäsi vaaliohjelmien ympä- 
rillä käytävään keskusteluun uuden elementin, mutta yleisesti ottaen vaaliohjelmien arviointikriteerit pysyivät ennallaan. Arvokas käytös, kiihkottomuus ja käytettyjen puheenvuorojen asiapitoisuus toimivat laadukkaan poliittisen keskustelun takeena.

\section{0-Iuvun mediatapahtumat}

Kuten edellä todettiin, vuodesta 1975 lähtien vaaliohjelmien vetovastuu siirtyi pysyvästi toimittajille, joskin edelleen 1980-luvulla Yleisradion ohjelmaneuvosto sääteli tiukasti vaaliohjelmien toteuttamisen reunaehtoja. 1980-luvun vaaliohjelmat noudattivat vuoden 1975 toteutustapaa. Vaalitenteissä poliitikoille esitettiin lyhyitä täsmäkysymyksiä, nostettiin esille poliitikkojen ja puolueiden aiempia tekoja ja linjauksia sekä kyseenalaistettiin poliitikkojen vastauksia. Suurissa vaalikeskusteluissa toimittajien rooli oli 1980-luvun alun vaaleissa vähäisempi ja poliitikkojen annettiin puhua keskeytyksittä varsin pitkäsanaisesti (Eduskuntavaalit 1979: Suuri vaalikeskustelu, Yle TV1 15.3.1979; Valitsijamiesvaalit 1982: Suuri vaalikeskustelu, Yle TV1 15.1.1982; Suuri vaalikeskustelu, Yle TV1 17.3.1983). Aktiivisemmin keskusteluihin osallistuivat 1980luvun jälkipuoliskolla toimittajat Leif Salmén ja Pekka Oksanen (Suuri vaalikeskustelu, Yle TV1 12.3.1987).

Vaikka vaaliohjelmien toteutuksessa ei suuria muutoksia 1980-luvulle tultaessa tapahtunutkaan, ajoittuu vuosikymmenen vaihteeseen monia merkittäviä murroskausia. Puoluelehdistön näivettyminen jatkui 1980-luvulle tultaessa ja sanomalehtijournalismia alkoivat yhä selvemmin ohjata kaupalliset päämäärät ja puoluepoliittinen sitoutumattomuus. Iltapäivälehtirintamalla uudenlaisia kilpailuasetelmia oli luomassa Uuden Suomen iltapäiväpainoksena vuonna 1980 aloittanut Iltalehti, joka haastoi yksin iltapäivälehtimarkkinoilla toimineen Ilta-Sanomat. (Pernaa \& Railo 2006.)

Politiikassa erään aikakauden päätöstä symboloi 25 vuotta presidenttinä toimineen Urho Kekkosen sairastuminen ja ero presidentin tehtävistä. Kekkosen väistymisen jälkeen politiikan kenttä oli avoinna uusille toimijoille ja uusille toimintatavoille. Jälkeenpäin on arvioitu, että Kekkosen ero avasi monia patoja niin politiikassa kuin journalismissakin. Sanomalehdistön politiikan journalismissa Kekkosen ero ja erityisesti hänen sairautensa salaaminen aiheutti kriittisen vastareaktion ja 1960- ja 70-lukujen arvostava suhtautuminen politiikkaan alkoi väistyä aiempaa kriittisemmän politiikan journalismin tieltä. (Pernaa \& Railo 2006, 25-26; Herkman 2011, 163-164.)

Vuoden 1982 presidentinvaalit toimivat eräänlaisena avauksena uudenlaiselle politiikan journalismille myös suhteessa vaaliohjelmiin ja televisioon. Keskustelua poliitikkojen persoonista ja yksityiselämästä oli käyty julkisuudessa jo 1970-luvulla, mutta keskustelun foorumeina olivat olleet ensisijaisesti aikakauslehdet. (Ks. esim. Railo 2011; Ruoho \& Saarenmaa 2011; Herkman 2011, 136.) Vuoden 1982 presidentinvaalien ennakkoasetelma tarjosi kuitenkin hyvät lähtökohdat ehdokkaiden henkilökohtaisten ominaisuuksien arviointiin myös päivälehdissä. Esimerkiksi Helsingin Sanomat julkaisi vaalien alla poikkeuksellisen suorasukaisen ehdokasesittelysarjan, jossa kuvailtiin vapain sanakääntein niin ehdokkaiden luonteenpiirteitä kuin ulkonäköäkin 
(Savola 1982, 37-81). Tyylilaji oli samankaltainen kuin vaalien alla julkaistussa ja kohua herättäneessä Tamminiemen pesänjakajat -teoksessa, jossa käsiteltiin maalailevaan tyyliin poliitikkojen heikkouksia ja yksityiselämää (Lauantaiseura 1981). Teoksen on jälkeenpäin arvioitu avanneen tietä aiempaa kriittisemmälle politiikan journalismille (Hämäläinen 2002, 35, 70-73; Herkman 2011, 164).

Vaaleihin ennakkosuosikkina lähteneen SDP:n Mauno Koiviston gallupsuosioon liitettiin jo ennen vaaleja hänen persoonallisuutensa, jonka katsottiin rakentuneen erityisesti televisiossa. Television vaalitentissä toimittaja Antero Kekkonen kysyikin Koivistolta, olisiko esimerkiksi Ståhlbergillä tai J. K. Paasikivellä, joiden ulosantia pidettiin 1980-luvun näkökulmasta heikkona, ollut mitään mahdollisuuksia tulla valituksia galluptutkimusten ja television aikakaudella. Antero Kekkonen viittasi puheenvuorossaan erityisesti gallupuutisoinnin ohjausvaikutuksiin ja television tapaan nostaa ehdokkaista esiin uusia piirteitä. (Vaalitentti: Mauno Koivisto, Yle TV1 11.1.1982.)

Yleisesti ottaen tiedotusvälineiden kasvanut mielenkiinto ehdokkaiden henkilökohtaisia ominaisuuksia ja persoonia kohtaan oli omiaan nostamaan myös television aikaisempaa näkyvämpään rooliin vaalikampailussa, sillä nimenomaan televisiossa ehdokkaiden arveltiin paljastavan jotain olennaista itsestään ja persoonastaan. Julkisuudessa alettiin jälleen puhua televisiovaaleista ja jopa televisiopresidentistä (IS 3.11.1981). Kehitys liittyi myös voimakkaaseen poliitikkokuvan muutokseen, jossa poliitikkoa ei nähty enää ainoastaan puolueen ja aatteen edustajana, vaan yksilönä ja persoonana, jolla oli suurta symboliarvoa koko puolueelle.

Tapa hahmottaa politiikkaa ei tietenkään muuttunut äkillisesti presidentinvaalien alla, vaan kehitys oli saanut alkunsa jo 1970-luvulla, mutta presidentinvaalien uudenlainen asetelma tarjosi puitteet aiempaa henkilökeskeisemmälle lähestymistavalle. Ilta-Sanomissa esitetty arvio kuvaa oivallisella tavalla vuoden 1982 vaaleissa näkynyttä uudenlaista ajattelua, joka korosti aikakauden erityisyyttä ja muutosta vanhaan.

Presidentiltä vaaditaan nykyisin sellaisia ominaisuuksia, joita ei ennen ole tarvinnut. Miellyttävä ulkonäkö ei liene vähämerkityksisin. Sujuva huulenheitto tulee hyvänä kakkosena.( IS 18.1.1982)

Television vaaliohjelmia oli vielä 1970-luvun lopun vaaleissa moitittu merkityksettömiksi, mutta uudenlainen vaaliasetelma ja henkilökeskeisemmäksi muuttunut politiikkakäsitys nostivat television uuteen arvoon. Erityisesti iltapäivälehdille vaaliohjelmista tuli keskeinen osa niiden vaalijournalismia. Muutos oli paitsi määrällinen - juttuja oli huomattavasti enemmän kuin aiemmin - myös laadullinen: vaaliohjelmat nousivat yhä useammin iltapäivälehtien kansijutuiksi ja niistä laadittiin aukeaman kokoisia reportaaseja. Vaaliohjelmista tuli tärkeitä poliittisia tapahtumia, jotka alkoivat 1960- ja 1970-luvuista poiketen ylittää kaikkien sanomalehtien uutiskriteerit.

Ensimmäinen uusi piirre vaaliohjelmiin liittyneessä uutisoinnissa oli voimakkaan vastakkainasettelun rakentaminen toimittajien ja poliitikkojen välille. "Anssi KeskiVähälä joutui kuin hiiri väistelemään ylivoimaisen kissaparin, Antero Kekkosen ja Jyrki Koulumiehen, hyökkäyksiä. Haastattelijoilla tuntui tosiaan olevan ruutia", arvioitiin 
esimerkiksi Ilta-Sanomien pääkirjoituksessa (IS 6.1.1982). Ilta-Sanomien kolumnisti puolestaan arvioi Johannes Virolaisen pompottaneen tenttijöitään mennen tullen (IS 13.1.1982). Iltapäivälehtien kuvauksissa sekä poliitikot että heitä haastatelleet toimittajat muuttuivat televisiotähdiksi, joiden keskinäistä kilpailua äänestäjät ja television katsojat kutsuttiin todistamaan.

Myös tavat kuvailla poliitikkoja muuttuivat: "Holkeri ei ole päässyt tutusta kireydestään. Se näkyi pitkin eilistä tv-tenttiä. Vain harvoin hän pystyi vastaamaan vapautuneesti mihin vaikutti se, että Antero Kekkonen ja Jyrki Koulumies olivat sarjan viimeisessä osassa inhottavimmillaan", kerrottiin Ilta-Sanomien uutisessa Harri Holkerin tv-tentistä (IS 14.1.1982). "Vaalea, viileä, hillitty ja hallittu aaveratsun kesyttäjä astui televisioruutuun ja suitsitti mustan hevosen", analysoi puolestaan Iltalehti kannessaan (IL 14.1.1982). Kuvauksissa mielenkiintoinen piirre liittyy juuri niiden esiintuomaan visuaalisuuteen. Kirjoituksien kuvailut liittyivät usein juuri näköaistiin perustuviin havaintoihin. Kuten edellä todettiin, tämänkaltaisia analyyseja kirjoitettiin 1960- ja 1970-luvuilla vain harvoin.

Iltalehti ei tyytynyt ainoastaan kertomaan vaaliohjelmien tapahtumista, vaan lehden laajoissa juttusarjoissa toimittajat jalkautuivat vaaliohjelmien kulisseihin kiinnittäen huomiota erityisesti vallitsevaan tunnelmaan. Jutuissa kerrottiin tyypillisesti poliitikkojen saapumisesta TV-studioon, heidän tunnelmistaan ennen jännittävää televisiotenttiä. Tentin jälkeen poliitikkoja pyydettiin arvioimaan omaa suoritustaan. (Ks. esim. IL 13.1.1982; IL 14.1.1982; IL 16.1.1982.) Jutut muistuttivat monin tavoin television urheilujournalismia, jossa urheilijaa haastatellaan ennen suoritusta ja pyydetään jälkiarviot maalissa.

Vuoden 1982 presidentinvaalit eivät jääneet television vaaliohjelmien suhteen ainutlaatuisiksi vaaleiksi, sillä presidentinvaalien jälkeen televisio nousi pysyvästi osaksi sanomalehtien politiikan journalismia. Päivälehdet pitäytyivät vielä 1980-luvun alun vaaleissa perinteisemmässä asiapohjaisessa raportointityylissä, mutta myös niiden kirjoittelussa saattoi havaita muutoksia 1980-luvun jälkipuoliskon vaaleissa. Hyvänä esimerkkinä toimii vuoden 1987 eduskuntavaalien suureen vaalikeskusteluun liittynyt Helsingin Sanomien uutinen, jossa arvioitiin ehdokkaiden pukeutumista. "Monet ehdokkaat olivat pukeutuneet kodikkaasti villaan. Paavo Väyrynen oli jopa paitasillaan", uutisoi Helsingin sanomat (HS 13.3.1987).

1980-luku nosti myös vaaliohjelmia vetäneet toimittajat uudella tavalla julkisuuden valokeilaan. Aiemmin näkymättömämmistä toimittajista tuli mediapersoonia, joita haastateltiin vaalien alla lähes yhtä usein kuin poliitikkoja. Toimittajiin liittynyt keskustelu henkilöityi 1980-luvun alussa Antero Kekkoseen ja 1980-luvun jälkipuoliskolla Leif Salméniin, joiden valitsema aiempaa päällekäyvempi haastattelutyyli jakoi mielipiteitä. 1970-luvun keskusteluissa päällimmäisenä ollut kriittinen suhtautuminen toimittajien haastattelumetodeihin tuli esille myös 1980-luvun kirjoituksissa ja on kuulunut vaaliohjelmia käsittelevään journalismiin sittemminkin (Pitkänen 2006, 213-216). Viimeisenä uutena piirteenä 1980-luvun kirjoittelussa oli vahvistunut käsitys television vaikutusvallasta vaaleissa. Usein vaaliohjelmilla arvioitiin olleen vaaleissa ratkaiseva merkitys. Vuoden 1983 vaaleissa kokoomuksen puheenjohtaja Ilkka Suomi- 
sen arvioitiin esiintymisellään pilanneen gallupien povaamaan vaalivoiton. "Koituiko kohtaloksi televisio? Vain kaksi päivää erotti kokoomuksen vaalivoitosta", kyseltiin Iltalehdessä (IL 24.2.1983). Vuoden 1987 eduskuntavaaleissa suurelle yleisölle tuntematon vihreiden ehdokas Pekka Haavisto nosti arvioiden mukaan itsensä eduskuntaan onnistuneen televisioesiintymisen myötä. "Haavisto todisti television tehon", uutisoi Helsingin Sanomat (HS 18.3.1987). Kuten esimerkit osoittavat, arviot television vaaliohjelmien ratkaisevasta vaikutuksesta olivat 1980-Iuvulla varsin yleisiä. Ero 1960- ja 1970-lukujen journalismiin on silmiinpistävä.

Tarkasteltaessa 1980-lukua kokonaisuutena voidaan todeta, että suhtautuminen televisioon politiikan tapahtumapaikkana muuttui huomattavasti tultaessa 1970-luvulta 1980-luvulle. Merkittävin muutos tapahtui uutisjournalismissa, joka nosti vaaliohjelmat aiempaa keskeisempään rooliin vaalikampanjoinnissa. Muutoksen airueena toimivat erityisesti iltapäivälehdet, jotka alkoivat yhä useammin kuvata vaaliohjelmia ainutlaatuisina mediatapahtumina, joiden jännite rakentui toisaalta poliitikkojen keskinäiseen kilpailun varaan, toisaalta poliitikkojen ja toimittajien väliseen vastakkainasetteluun. Huomiota alettiin kiinnittää myös ehdokkaiden esiintymiseen ja poliitikkojen esiintymistä kutsuttiin arvioimaan milloin lukijat, milloin poliitikot, milloin tutkijat. (Ks. esim. IL 12.1.1982; IL 16.1.1982; IS 10.8.1983; HS 14.3.1987; IS 13.3.1987.) Vaaliohjelmia analysoivien kirjoitusten uudessa politiikkadiskurssissa tärkeää ei ollut enää yksinomaan se, mitä poliitikot sanoivat vaan myös se, millä tavoin poliitikot asiansa esittivät. Lehdissä arvioitiin yhä useammin ehdokkaiden karismaa ja persoonan vetovoimaisuutta, joiden ajateltiin saavan hahmon erityisesti televisiossa.

Daniel Dayan ja Elihu Katz (1992) ovat esittäneet, että televisio-ohjelmista tulee mediatapahtumia vasta kun ne muun muassa saavuttavat suuria katsojamääriä ja muut tiedotusvälineet alkavat rakentaa ja ylläpitää korkeita odotuksia tulevaa ohjelmaa kohtaan. Katsojamäärillä mitattuna television vaaliohjelmat olivat merkittäviä jo 1960-luvun lopulta lähtien, jolloin suuret vaalikeskustelut alkoivat tavoittaa yli miljoona suomalaista (Sisättö 1977, 115). Vaaliohjelmiin liittyneitä korkeita odotuksia alettiin luoda suomalaisessa sanomalehdistössä kuitenkin vasta 1980-luvulla. Sanomalehtien televisiosivuilla mainostettiin lyhyesti illan vaaliohjelmia jo 1960-luvulla, mutta vasta 1980-luvulla vaaliohjelmiin liittyvissä ennakkojutuissa alettiin korostaa television ainutlaatuista luonnetta politiikan tapahtumapaikkana.

1980-luvulle tultaessa vaaliohjelmiin liittyvän kirjoittelun volyymi kasvoi (ks. kuvio 1), mutta määrällistä muutostakin merkityksellisempi oli kirjoittelun laadullinen muutos. Vaaliohjelmista kirjoitettiin enemmän ja suurempia juttuja, spekulaatiot ehdokkaiden menestymisestä muuttuivat yhä yleisemmiksi ja vaaliohjelmien merkitystä alettiin korostaa yhä useammissa puheenvuoroissa. Sanomalehdet rakensivat kilpailuasetelmia ja jännitteitä vaaliohjelmissa esiintyvien poliitikkojen ja toimittajien välille. Erityisesti iltapäivälehtien maalailevat tunnelmakuvaukset loivat vaikutelmaa ainutlaatuisesta tapahtumasta. Aineiston perusteella onkin mahdollista arvioida, että 1980-luvun kirjoittelu nosti television vaalien mahtitekijäksi ja vahvisti sen asemaa vaalikampanjoinnin keskeisimpänä tiedostusvälineenä. 
2000-luvun perspektiivistä voidaan todeta, että 1980-luvulla omaksuttu tapa suhtautua television vaaliohjelmiin on vallitseva myös 2000-luvun Suomessa. Siihen eivät ole vaikuttaneet ne tavat, joilla vaaliohjelmia on sittemmin tehty. Yhdeksi vakiintuneeksi tavaksi arvioida johtavien poliitikkojen kompetenssia on tullut analysoida heidän esiintymistään television vaaliohjelmissa (Pitkänen 2006, 209-221).

\section{Vaaliohjelmat poliittiskulttuurisen muutoksen kuvana}

Olen edellä kuvannut sitä, miten sanomalehdet suhtautuivat televisioon ja erityisesti television vaaliohjelmiin 1960-, 1970- ja 1980-luvuilla. Sanomalehdistön suhtautumisessa silmiinpistävin muutos sijoittuu 1970- ja 1980-lukujen taitteeseen, jolloin sanomalehdistö, iltapäivälehdet etunenässä, nostivat television vaaliohjelmat vaalikampanjoinnin ytimeen.

Miksi vaaliohjelmat nostettiin sanomalehdistössä vaalikampanjoinnin keskiöön vasta 1980-luvulla, vaikka moni seikka puhui television suuren merkityksen puolesta jo 1960- ja 1970-luvuilla? Television välityksellä saattoi tavoittaa valtaosan suomalaisista jo 1960-luvun lopulla (Pernaa 2007, 34), jolloin vaaliohjelmat keräsivät poikkeuksetta yli miljoona katsojaa (Sisättö 1977, 115). Myös poliitikot arvostivat televisiota kampanjoinnin välineenä jo 1960-luvulta lähtien (Pernaa 2007, 32). Televisio ylipäätään herätti tunteikasta keskustelua ja esimerkiksi 1960- ja 1970-lukujen taitteessa sanomalehtien pääkirjoitukset, kolumnit ja mielipidepalstat täyttyivät Yleisradiota ja sen ohjelmistoa käsittelevistä kirjoituksista. Sanomalehtitoimittajille television vaaliohjelmat olivat kuitenkin aina 1970-luvun lopulle saakka toissijainen politiikan foorumi, johon ei kiinnitetty erityishuomiota. Mikseivät sanomalehdet huomioineet television vaaliohjelmia tärkeinä vaikuttamisen paikkoina, kun televisioon ja Yleisradioon suhtauduttiin muuten niin suurella intohimolla?

Ensinnä selitystä voi hakea sanomalehtien ja television keskinäisestä kilpailuasetelmasta. Television yleistyminen koettiin sanomalehdissä 1960- ja 1970-luvuilla uhkaksi, koska sen arvioitiin heikentävän sanomalehtien yhteiskunnallista asemaa (Kilpi 2007, 142). On mahdollista, etteivät lehdet halunneet korostaa kilpailevan tiedotusvälineen yhteiskunnallista merkittävyyttä. Sen sijaan ne painottivat vaalijournalismissa asiakysymyksiä, joiden käsittelyssä lehdistö oli vahvoilla. 1980-luvulle tultaessa televisio oli jo vakiinnuttanut asemansa suomalaisessa mediakentässä, joten televisiosisällöistä uutisoimiseen ei enää liittynyt erityisiä uhkakuvia.

Toiseksi sanomalehdistön kirjoittelussa tapahtuneet muutokset voivat liittyä myös poliittiseen kulttuuriin. Aatteelliset ristiriidat olivat 1960- ja 1970-luvuilla voimakkaita, ja puolueiden yhteiskunnallisissa tavoitteissa oli suuria eroja. Tästä johtuen aatteet ja erilaiset yhteiskunnalliset tavoitteenasettelut saivat keskeisen roolin aikakauden poliittisessa kulttuurissa. Sanomalehtien kirjoittelun voidaan katsoa ilmentävän aikakauden vallitsevia tapoja jäsentää politiikkaa. 1980-luvulle tultaessa aatteelliset ristiriidat alkoivat heikentyä, puolueet samankaltaistua ja kansalaisten kiinnittyminen puolueisiin oheni (Mickelsson 2007, 186-239). Tämä siirsi politiikan julkisuuden pai- 
nopistettä asioista henkilöihin. Keskustelu poliitikkojen imagoista ja puolueiden julkisuuskuvista yleistyi ja julkisuudessa alettiin kiinnittää huomiota poliitikkojen yksityiselämään ja persoonaan (Pernaa \& Railo 2006). Samalla television merkitys politiikan julkisena areenana kasvoi, sillä juuri television ajateltiin tarjoavan kansalaisille mahdollisuuden arvioida politiikkojen henkilökohtaisia ominaisuuksia uudella tavalla.

Poliittiskulttuuristen muutosten keskeisyyttä korostaa myös se, ettei vaaliohjelmiin liittynyt kirjoittelu ole kiinnittynyt vaaliohjelmien toteutukseen. Vaaliohjelmien toteutuksen näkökulmasta tärkeimmät käännekohdat sijoittuvat 1970-luvun puoliväliin, jolloin vaaliohjelmia ruvettiin tekemään toimittajien johdolla, sekä 1990-luvun alkuun, jolloin Yleisradio luopui tasapuolisuusperiaatteestaan ja antoi ohjelmien toteutuksessa enemmän painoarvoa journalistisille lähtökohdille. 1990-luvulla myös muut toimijat saivat luvan tehdä omia vaaliohjelmiaan. Esimerkiksi MTV 3 lähetti ensimmäisen vaalikeskustelunsa vuoden 1991 eduskuntavaalien alla. (Moring \& Himmelstein 1993, 44-47.) 1990- ja 2000-luvulla vaaliohjelmiin lisättiin runsaasti henkilöiden keskeisyyttä korostavia elementtejä ja ohjelmissa alettiin korostaa poliitikkojen välisiä kilpailuasetelmia esimerkiksi erilaisin kaksintaisteluin (Pernaa \& Pitkänen 2010, 211-212).

Kumpikaan edellä kuvatuista vaaliohjelmien toteutukseen liittyvistä käännekohdista ei vaikuttanut olennaisella tavalla siihen, millä tavoin sanomalehdet vaaliohjelmiin suhtautuivat. 1970-luvun puolivälin journalistisemmat vaaliohjelmat pysyivät sanomalehtien kampanjajournalismin marginaalissa. 1980-luvun journalismissa alettiin korostaa imagoiden merkitystä ja television keskeistä roolia politiikassa, jolloin myös vaaliohjelmat nousivat kampanjajulkisuuden ytimeen. 1990-luvulle tultaessa poliitikotkin olivat valmiita kehittämään television vaaliohjelmistoa ja lisäämään toimittajien mahdollisuuksia käyttää journalistista harkintaa vaaliohjelmien toteutuksessa. Onkin mahdollista, että sanomalehdistön 1980-luvulla omaksumat uudet tavat käsitellä vaaliohjelmia vaikuttivat omalta osaltaan siihen, millä tavoin vaaliohjelmia alettiin 1990-luvulla toteuttaa.

Kaiken kaikkiaan vaaliohjelmiin liittynyt kirjoittelu osoittaa, että vaaliohjelmille sanomalehdistössä annetut merkitykset ovat olleet tiiviisti kytköksissä laajempiin yhteiskunnallisiin kehityskulkuihin. 1960- ja 1970-lukujen sanomalehtijournalismi todistaa, ettei televisio automaattisesti tehnyt politiikasta aiempaa henkilökeskeisempää ja viihteellisempää, kuten usein esitetään (Postman 1986; Bordieu 1998). 1980luvun muuttuva yhteiskunnallinen ilmapiiri ja poliittinen kulttuuri yhdessä aiempaa markkinaehtoisemmin toimivan median kanssa suuntasi yleisön huomion kohti poliitikkojen imagoita ja puolueista välittyviä mielikuvia. Vasta tämä kehitys nosti television yhdeksi politiikan keskeisimmistä foorumeista. 


\section{Viitteet}

1 Artikkelin aineisto pitää sisällään 538 lehtikirjoitusta. Aineistot on kerätty kustakin vaaleista kahden kuukauden ajalta ennen vaalipäivää ja viikko vaalien jälkeen.

2 Ylen tv-arkistoon on tallennettu television vaaliohjelmia hajanaisesti 1960- ja 1970-luvuilta. 1980-2000-luvuilta ohjelmat ovat tallessa kattavasti. 1960-Iuvun vaaliohjelmien osalta aineistoa on ollut mahdollista täydentää radioarkiston avulla, sillä 1970-luvun alkuun saakka suuret vaalikeskustelut esitettiin radion ja television yhteislähetyksinä.

3 Yleisradion leikearkistoon on kerätty vaaliohjelmia käsitteleviä kirjoituksia 1970-luvun alusta saakka. Aineisto ei ole systemaattinen, vaan pitää sisällään sekalaisen joukon kirjoituksia suomalaisista sanomalehdistä.

$4 \quad$ Helsingin Sanomien referoiva tyyli liittyi osin myös Suomen ulkopoliittiseen tilanteeseen 196o-luvun lopulla. Virallisessa ulkopoliittisessa liturgiassa yksittäisten sanojen merkitys oli suuri. On mahdollista, että Helsingin Sanomat referoi kirjoitukset sanasta sanaan, koska se halusi välttää tekemästä ulkopolitiikkaan liittyviä tulkintoja. Suomalaisen sanomalehdistön itsesensuurista ks. esim. Salminen 1996.

5 Raimo Salokankaan Yleisradion historiassa on hyvä yleiskuvaus aikakauden keskeisimmistä ristiriitakysymyksistä ja kehityskuluista. Salokangas 1996, 205-249.

\section{Kirjallisuus}

Aula, Maria Kaisa (1991). Poliitikkojen ja toimittajien suhteet murroksessa? Tutkimus Yleisradion politiikan toimittajien ammatti-identiteetistä 1980-luvulla. Tutkimusraportti 5. Tutkimus- ja kehitysosasto, Helsinki: Yleisradio.

Bastiansen, Henrik G. (2006). Da avisene møtte TV. Partipressen, politikken og fjernsynet 1960-1972. Oslo: Universitetet i Oslo.

Bourdieu, Pierre (1998). On television. New York: New Press, cop.

Dayan, Daniel \& Katz, Elihu (1992). Media Events. The Live Broadcasting of History. Cambridge: Harvard University Press.

Elfving, Sari (2008). Taikalaatikko ja tunteiden tulkit. Televisio-ohjelmia ja -esiintyjiä koskeva kirjoittelu suomalaisissa lehdissä 1960- ja 70-luvuilla. Tampere: Tampere University Press.

Ellis, John (2000). Seeing Things. Television in the Age of Uncertainty. London: I.B.Tauris Publisher.

Fiske, John (1987). Television Culture. London: Methuen.

Hemánus, Pertti (1972). Reporadion nousu ja tuho. Helsinki: Otava.

Heiskanen, Ilkka (1986). Televisio, elämäntapatutkimus ja todellisuuden määritty/äminen. Teoksessa: Heikkinen Kalle (toim.). Kymmenen esseetä elämäntavasta. Helsinki: Oy Yleisradio Ab, 93-136.

Herkman, Juha (2005). Kaupallisen television ja iltapäivälehtien avioliitto. Median markkinoituminen ja televisioituminen. Tampere: Vastapaino.

Herkman, Juha (2008). Intermediaalisuus ja televisiotutkimuksen metodologia. Haasteita, mahdollisuuksia ja ongelmia. Teoksessa: Keinonen, Heidi; Ala-Fossi, Marko \& Herkman, Juha (toim.). Radio- ja televisiotutkimuksen metodologiaa. Näkökulmia sähköisen viestinnän tutkimiseen. Tampere: Tampere University Press, 153-166.

Herkman, Juha (2011). Politiikka ja mediajulkisuus. Tampere: Vastapaino.

Hujanen, Taisto \& Weibull, Lennart (2010). The Public Reception of Early Television: When Television was New in the Nordic Countries. Gripsrud, Jostein \& Weibull, Lennart (toim.). Media, Markets \& Public Spheres: European Media at the Crossroads. Bristol: Intellect, 97-114.

Hämäläinen, Unto (2002). Onko tämä skuuppi? Politiikan toimittajan työtä 1950-luvulta nykypäivään. Uusikaupunki: Politiikan toimittajat ry.

Ilmonen, Kari (1996). Tekniikka kaiken perusta. Yleisradion historia 1926 - 1996. 3.osa. Helsinki: Yleisradio. Isotalus, Pekka (toim.) (1998). Kaveri vai peluri. Poliitikko mediassa. Jyväskylä: Atena.

Isotalus, Pekka (1996). Vaalikeskustelu ylittää uutiskynnyksen. Mitä sanomalehdet kirjoittavat television vaaliohjelmista. Politiikka 38 (4), 229-239. 
Johansson, Bengt (2008). Popularized Election Coverage? News Coverage of Swedish Parliamentary Election Campaigns 1979-2006. Teoksessa: Strömbäck, Jesper; Ørsten, Mark \& Aalberg, Toril (toim.). Communicating Politics: Political Communication in the Nordic Countries. Nordicom, 181-193.

Keinonen, Heidi (2011). Kamppailu yleistelevisiosta. TES-TV:n, Mainos-TV:n ja Tesvision merkitykset suomalaisessa televisiokulttuurissa 1956-1964. Tampere: Tampere University Press.

Kilpi, Timo (2007). Ilta-Sanomat. Uutisia, historiaa ja puheenaiheita. Helsinki: WSOY.

Kivioja, Pasi (2008). Iltapäivälehdet mediakentän ja yhteiskunnan muutoksessa. Tampere: Tampereen yliopisto, journalismin tutkimusyksikkö.

Koski, Markku (2010). "Hohto on mennyt herrana olemisesta". Televisio ja poliitikko. Tampere: Vastapaino.

Kunelius, Risto; Noppari, Elina \& Reunanen, Esa (2009). Media vallan verkoissa. Journalismin tutkimusyksikkö. Julkaisuja. Sarja A 112. Tampere: Tampereen yliopisto.

Langer, Aná Ines (2007). A Historical Exploration of the Personalisation of Politics in the Print Media: The British Prime Ministers (1945-1999). Parliamentary Affairs (2007) 60 (3), 371-387.

Lauantaiseura (1981). Tamminiemen pesänjakajat: Kekkonen lähtee - kuka tulee? Tampere: Kustannusvaihe.

Malin, Kimmo (2010). Mörökölleistä hymyhuuliksi. Miten puoluejohtajien viestintäkäyttäytyminen ja -tyylit television vaalikeskusteluissa ovat muuttuneet vuosien 1987 ja 2007 välillä? Pro gradu -tutkielma. Helsinki: Helsingin yliopisto.

McKinney, Mitchell S. \& Carlin, Diana P. (2004). Political campaign debates. Teoksessa Kaid, Lynda Lee (toim.). Handbook of Political Communication Research. London: LEA's Communication Series, 203234.

Mickelsson, Rauli (2007). Suomen puolueet: historia, muutos ja nykypäivä. Tampere: Vastapaino.

Moring, Tom \& Himmelstein, Hal (1993). Politiikkaa riisuttuna. Tutkimusraportti 6/1993. Helsinki: YLE.

Nikunen, Kaarina (2005). Faniuden aika - Kolme tapausta televisio-ohjelmien faniudesta vuosituhannen taitteen Suomessa. Tampere: Tampere University Press.

Peltola, Pekka (1970). Raportti vaalikeskusteluiden vaiheilta. Helsinki: Oy. Yleisradio Ab.

Pernaa, Ville (2007). Neljäs valtiomahti haastaa ensimmäisen. Teoksessa: Pernaa, Ville; Laaksovirta, Tuula H. \& Lumme, Pentti (toim.). Suomen eduskunta sata vuotta, osa 10. Ensimmäinen ja neljäs valtiomahti. Helsinki: Edita.

Pernaa, Ville \& Pitkänen, Ville (2006). Poliitikot taistelivat, media kertoo. Suomalaisen politiikan mediapelejä 1981-2006. Helsinki: Ajatuskirjat.

Pernaa, Ville \& Pitkänen, Ville (2010): Median ja politiikan muuttuvat suhteet. Teoksessa Meriranta, Marjo (toim.). Mediakasvatuksen käsikirja. Kuopio: Unipress, 195-229.

Pernaa, Ville \& Railo, Erkka (2006). Valtapolitiikasta tunnepolitiikkaan. Teoksessa: Ville Pernaa \& Ville Pitkänen (toim.). Poliitikot taistelivat, media kertoo. Suomalaisen politiikan mediapelejä 1981-2006. Helsinki: Ajatuskirjat, 17-54.

Pesonen, Pertti (1972). Valitsijain vaalikiinnostus. Teoksessa: Pertti Pesonen (toim.). Protestivaalit, nuorisovaalit. Politiikan tutkimuksia 12. Helsinki: Ylioppilastuki ry., 67-100.

Pitkänen, Ville (2009). Politiikan journalismin yhteiskunnallinen tehtävä. Teoksessa: Pernaa, Ville; Niemi, Mari K. \& Pitkänen, Ville (toim.). Politiikan journalismin tila Suomessa. Turku: Kirja-Aurora, 79-108.

Pitkänen, Ville (2006). Kun ylivoimainen kansansuosikki haastetaan presidentinvaaleissa. Teoksessa: Pernaa, Ville \& Pitkänen, Ville (toim.). Poliitikot taistelivat, media kertoo. Suomalaisen politiikan mediapelejä 1981-2006. Helsinki: Ajatuskirjat, 193-227.

Postman, Neil (1986). Amusing ourselves to Death: Public Discourse in the Age of Show Business. Harmondsworth: Penguin Books.

Railo, Erkka (2011). Henkilökohtainen on poliittista. Neuvottelu politiikan sukupuolittuneesta työnjaosta Annan julkaisemissa poliitikkojen henkilökuvissa vuosina 1975-2005. Sarja C 310. Turku: Turun yliopiston julkaisuja.

Ruoho, liris (2001). Utility Drama. Making of and Talking about the Serial Drama in Finland. Tampere: Tampere University Press.

Ruoho, liris \& Saarenmaa, Laura (2011). Edunvalvonnasta elämänpolitiikkaan. Naistenlehdet journalismina ja julkisuutena. Tampere: Tampereen yliopisto, journalismin tutkimusyksikkö.

Salmi, Hannu (1996). "Atoomipommilla kuuhun!" tekniikan mentaalihistoriaa. Kleio ja Nykypäivä. Helsinki: Edita. 
Salminen, Esko (2006). Mediavallan aika. Helsinki: Edita.

Salminen, Esko (1996). Vaikeneva valtiomahti? Neuvostoliitto/Venäjä Suomen lehdistössä 1968-1991. Kleio ja Nykypäivä. Helsinki: Edita.

Salminen, Esko (1988). Sitoutumattomuuden ja laajenevan informaation aika 1950-1980. Teoksessa: Tommila, Päiviö (toim.). Suomen lehdistön historia 3. Sanomalehdistö sodan murroksesta 1980-luvulle. Kuopio: Kustannuskiila, 141-305.

Salokangas, Raimo (1996). Aikansa oloinen. Yleisradion historia 1949-1996. Osa 2. Helsinki: Yleisradio Oy.

Savola, Hannu (toim.) (1982). Näin saatiin presidentti. Raportti Kekkosen kauden päättymisestä ja vuosikymmenen presidentinvaaleista 1982. Helsinki: Sanoma Oy.

Sisättö, Seppo (1977). Televisio ja vaalit. Tutkimus Suomen television esittämistä eduskunta- ja kunnallisvaaliohjelmien seuraamisesta vuosina 1960-1975. Helsinki: Valtiotieteellinen yhdistys.

Suhonen, Pertti (1975). Yleisradion vaaliohjelmien yleisö. Sarja B 10 Oy. Helsinki: Yleisradio Ab.

Tommila, Päiviö \& Salokangas, Raimo (1998). Sanomia kaikille. Suomen lehdistön historia. Kleio ja nykypäivä. Helsinki: Edita.

Väliverronen, Jari \& Kunelius, Risto (2009). Politiikan journalismi medioitumisen aikakaudella. Teoksessa: Väliverronen, Esa (toim.). Journalismi murroksessa. Helsinki: Gaudeamus.

Wiio, Osmo A. \& Nordenstreng, Kaarle (1972). Radio ja televisio poliittisten mielikuvien välittäjänä. Teoksessa: Pesonen, Pertti (toim.). Protestivaalit, nuorisovaalit. Politiikan tutkimuksia 12. Helsinki: Ylioppilastuki ry., 101-128.

Williams, Raymond (1975). Television. Technology and Cultural Form. New York: Schocken Books.

\section{Sanomalehtiaineistot}

Helsingin Sanomat 15.11.1961 - 12.2 1962.

Helsingin Sanomat 20.1.1966 - 28.3.1966.

Helsingin Sanomat 15.11.1967 - 23.1.1968.

Helsingin Sanomat 15.1.1970 - 23.3.1970.

Helsingin Sanomat 2.11.1971 - 10.1.1972

Helsingin Sanomat 21.7.1975 - 29.9.1975.

Helsingin Sanomat 15.11.1977 - 23.1.1977.

Helsingin Sanomat 18.1.1979 - 26.3.1979.

Helsingin Sanomat 17.11.1981 - 25.1.1982.

Helsingin Sanomat 20.1.1983 - 28.3.1983.

Helsingin Sanomat 15.1.1987 - 23.1.1987.

Helsingin Sanomat 1.12.1987 - 8.2.1988.

Aamulehti 15.11.1961 - 12.2 1962.

Aamulehti 20.1.1966 - 28.3.1966.

Aamulehti 15.11.1967 - 23.1.1968.

Aamulehti 15.1.1970 - 23.3.1970.

Aamulehti 2.11.1971 - 10.1.1972

Aamulehti 21.7.1975 - 29.9.1975.

Aamulehti 15.11.1977 - 23.1.1977.

Aamulehti 18.1.1979 - 26.3.1979.

Aamulehti 17.11.1981 - 25.1.1982.

Aamulehti 20.1.1983 - 28.3.1983.

Aamulehti 15.1.1987 - 23.1.1987.

Aamulehti 1.12.1987-8.2.1988. 
Ilta-Sanomat 15.11.1961 - 12.21962.

Ilta-Sanomat 20.1.1966 - 28.3.1966.

Ilta-Sanomat 15.11.1967 - 23.1.1968.

Ilta-Sanomat 15.1.1970 - 23.3.1970.

Ilta-Sanomat 2.11.1971 - 10.1.1972

Ilta-Sanomat 21.7.1975 - 29.9.1975.

Ilta-Sanomat 15.11.1977 - 23.1.1977.

Ilta-Sanomat 18.1.1979 - 26.3.1979.

Ilta-Sanomat 17.11.1981 - 25.1.1982.

Ilta-Sanomat 20.1.1983 - 28.3.1983.

Ilta-Sanomat 15.1.1987 - 23.1.1987.

Ilta-Sanomat 1.12.1987-8.2.1988.

Iltalehti 17.11.1981 - 25.1.1982.

Iltalehti 20.1.1983 - 28.3.1983.

Iltalehti 15.1.1987- 23.1.1987.

Iltalehti 1.12.1987-8.2.1988.

Vaaliohjelmia käsittelevät sanomalehtikirjoitukset. Yleisradion leikearkisto.

\section{Televisioaineistot}

Valitsijamiesvaalikeskustelu 30.12.1968. Yleisradion TV-arkisto.

Presidentinvaalitentti: Urho Kekkonen 27.12.1968. Yleisradion TV-arkisto.

Peukaloruuvi (SMP) 22.9.1969. Yleisradion TV-arkisto.

Kohti vaaleja (SDP) 4.3.1970. Yleisradion TV-arkisto.

Vaalien kynnyksellä 30.12.1971. Yleisradion TV-arkisto.

Linjanvetoa 28.11.1971. Yleisradion TV-arkisto.

Suuri vaalikeskustelu 18.9.1975. Yleisradion TV-arkisto.

Eduskuntavaalit 1979: Suuri vaalikeskustelu 15.3.1979. Yleisradion TV-arkisto.

Valitsijamiesvaalit 1982: Suuri vaalikeskustelu 15.1.1982. Yleisradion TV-arkisto.

Suuri vaalikeskustelu 17.3.1983. Yleisradion TV-arkisto.

Suuri vaalikeskustelu 12.3.1987. Yleisradion TV-arkisto.

Presidentti '88 28.1.1988. Yleisradion TV-arkisto.

Kuvaruudun ehdoilla 15.2.1995. Yleisradion TV-arkisto.

\section{Radioaineistot}

Suuri vaalikeskustelu valitsijamiesvaalit 9.1.1962. Yleisradion radioarkisto.

Suuri vaalikeskustelu 12.1.1968. Yleisradion radioarkisto. 